\title{
VIBRATIONAL CHARACTERISTICS OF AIRCRAFT EXHAUST T50 THERMOCOUPLE
}

\author{
Siddesha $T^{1}$, Madhusudhana $S^{2,}$ Lingaraj $L^{3}$ \\ ${ }^{1,2,3}$ Assistant Professor, Department of Mechanical Engineering. TJIT, Bangalore. \\ siddubavish@gmail.com
}

\begin{abstract}
A limiting factor in a gas turbine engine is the temperature of the turbine section. The temperature of a turbine section must be monitored closely to prevent overheating the turbine blades and other exhaust section components. One common way of monitoring the temperature of a turbine section is with an EGT gauge. The main focus of this project work is to analyse and validate the T50 thermocouple for static and fatigue load requirement using finite element analysis tool Ansys workbench14.5.Analysis results are correlated and validated using empherical relations. In case of static nonlinear analysis, bolt pretension has been validated using bolt stiffness relation. In case of dynamic analysis thermocouple response has been validated using harmonic sine equation. The proposed design meets the design guidelines of FAA for critical engine operating conditions.
\end{abstract}

Keywords: Aerospace, FEM, Fatigue Strength, Nonlinear Static Analysis.

\section{INTRODUCTION}

Engineering machines and structure in service, experiences vibration, and their design generally requires consideration of their dynamic behaviour. The type of input forces experienced by different components of aerospace in service is dynamic. The progressive, localized and permanent structure change that occurs in a material subjected to repeated or fluctuating strains at nominal stresses that have maximum values less than the tensile strength of the material which may culminates in cracks and causes fracture after a sufficient number of fluctuations is known as fatigue. Fatigue and durability design of any component of an aerospace structure plays an important role to ensure reliability. The total damage and life of a structure is due to a combination of static and dynamic loads arising from engine vibrations, service load. The basic aim is to enable fatigue life calculations to be done at the design stage of a development process. It is necessary to clarify the term fatigue as the estimation of fatigue life when the stress or strain histories obtained from the structure or component.

\subsection{Exhaust Gas Temperature Thermocouple}

A limiting factor in a gas turbine engine is the temperature of the turbine section. The temperature of a turbine section must be Monitored closely to prevent overheating the turbine blades And other exhaust section components. One common way of monitoring the temperature of a turbine section is with an EGT gauge. EGT is an engine operating limit used to monitor overall engine operating conditions.

\section{SCOPE OF WORK}

The Main focus of this Project work is to evaluate the vibrational characteristics of aircraft exhaust T50 thermocouple. From Vibration analysis stress response output found.

\section{MATERIAL PROPERTIES}

Support tube and Simplex Element has been modeled with Inconnel 625.

Table 5.1 Mechanical properties of Inconnel 625 material

\begin{tabular}{|l|l|l|}
\hline SI.No & Description & Value \\
\hline 1 & Young's Modulus(E) & $1.478 * 10^{\wedge} 5 \mathrm{~N} / \mathrm{mm}^{2}$ \\
\hline 2 & Poisson's Ratio $\left.{ }^{\vartheta}\right)$ & 0.29 \\
\hline 3 & Density $\left({ }^{\rho}\right)$ & $8.44 * 10^{\wedge}-6 \mathrm{Kg} / \mathrm{mm}^{3}$ \\
\hline 4 & Yield Strength $(\sigma y)$ & $262 \mathrm{~N} / \mathrm{mm}^{2}$ \\
\hline 5 & $\begin{array}{l}\text { Ultimate } \\
\text { Strength }(\sigma u)\end{array}$ & $675.6 \mathrm{~N} / \mathrm{mm}^{2}$ \\
\hline
\end{tabular}

2. Housing, Lid and terminal has been modeled with AISI304 steel

Table 5.2 Mechanical properties of AISI304 steel material

\begin{tabular}{|l|l|l|}
\hline SI.No & Description & Value \\
\hline 1 & Young's Modulus(E) & $1.79^{*} 10^{\wedge} 5 \mathrm{~N} / \mathrm{mm}^{2}$ \\
\hline 2 & ${\text { Poisson's Ratio }\left({ }^{\vartheta}\right)}^{\ominus}$ & 0.27 \\
\hline 3 & Density $\left({ }^{\rho}\right)$ & $7.75^{*} 10^{\wedge}-6 \mathrm{Kg} / \mathrm{mm}^{3}$ \\
\hline 4 & Yield Strength $\left({ }^{\sigma y}\right)$ & $99.7 \mathrm{~N} / \mathrm{mm}^{2}$ \\
\hline 5 & Ultimate Strength $\left({ }^{\sigma u}\right)$ & $310.2 \mathrm{~N} / \mathrm{mm}^{2}$ \\
\hline
\end{tabular}

3. Bolt has been modeled with Inco 718 .

\begin{tabular}{|c|c|c|}
\hline \multicolumn{2}{|c|}{\begin{tabular}{l|l} 
SI.No & Description
\end{tabular}} & Value \\
\hline 1 & Young's Modulus(E) & $1.79 * 10^{\wedge} 5 \mathrm{~N} / \mathrm{mm}^{2}$ \\
\hline 2 & Poisson's Ratio $\left({ }^{\theta}\right)$ & 0.27 \\
\hline 3 & $\operatorname{Density}\left({ }^{\rho}\right)$ & $7.75^{*} 10^{\wedge}-6 \mathrm{Kg} / \mathrm{mm}^{3}$ \\
\hline 4 & Yield Strength $\left({ }^{\sigma y)}\right.$ & $99.7 \mathrm{~N} / \mathrm{mm}^{2}$ \\
\hline 5 & Ultimate Strength( $\left.{ }^{\sigma u}\right)$ & $310.2 \mathrm{~N} / \mathrm{mm}^{2}$ \\
\hline
\end{tabular}




\section{CATIA MODEL}

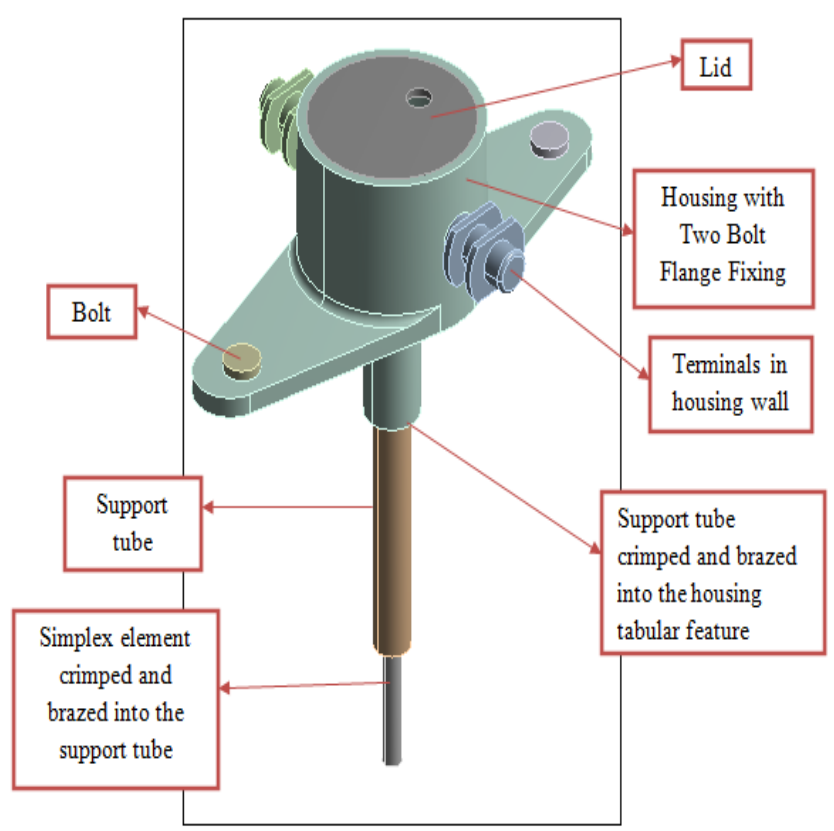

Fig 1 Representation of T50 thermocouple in 3d view

\section{FINITE ELEMENTS MODEL}

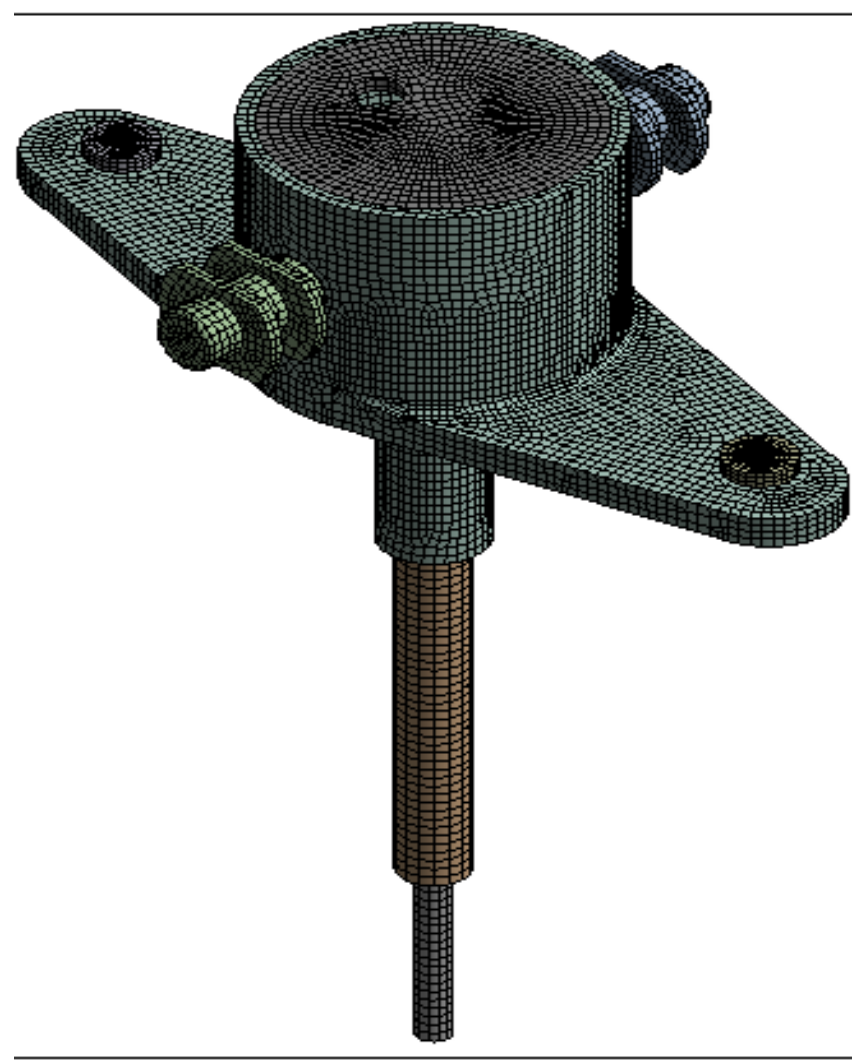

Fig 2. Finite element model of T50 thermocouple.

\section{VIBRATION ANALYSIS OF T50 THERMOCOUPLE}

The modal analysis has been performed for a frequency range of $0-2000 \mathrm{~Hz}$ and at $600 \mathrm{C}$.

\section{BOUNDARY AND LOADING CONDITIONS}

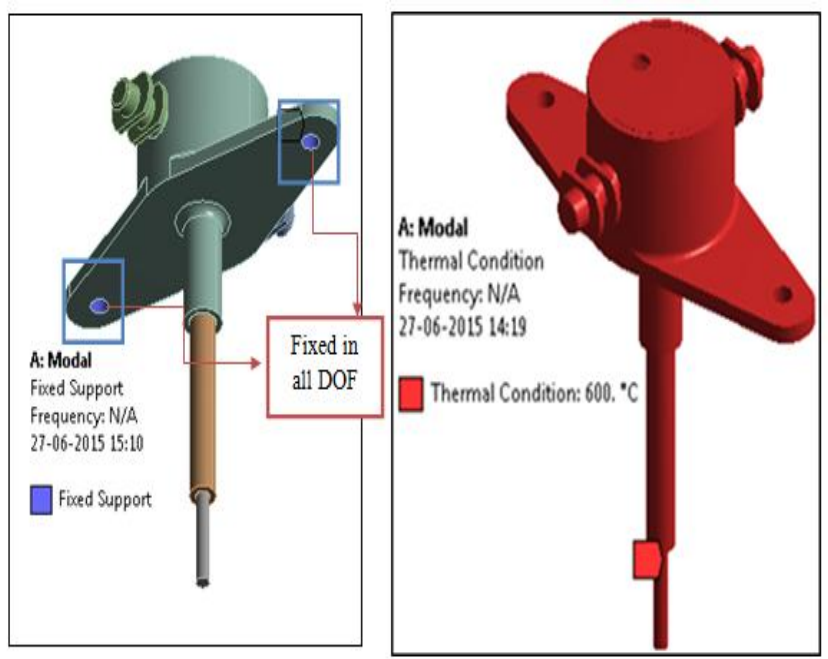

Fig 3 Boundary and Loading Conditions

\section{RESULTS \& DISCUSSION}

Total 2 modes are observed in the frequency range of 0 $2000 \mathrm{~Hz}$

Table 1 Modal frequencies of T50 thermocouple

\begin{tabular}{|l|l|l|}
\hline $\begin{array}{l}\text { Mode } \\
\text { no }\end{array}$ & Frequency $(\mathbf{H z})$ & Remarks \\
\hline 1 & 1168.3 & $\begin{array}{l}\text { Bending mode in } \\
\text { X-direction }\end{array}$ \\
\hline 2 & 1605.5 & $\begin{array}{l}\text { Bending Mode in } \\
\text { Y-direction }\end{array}$ \\
\hline
\end{tabular}

\section{$>\quad$ Mode Shapes}

Mode-1: Element bending mode in X-direction at 1168.3

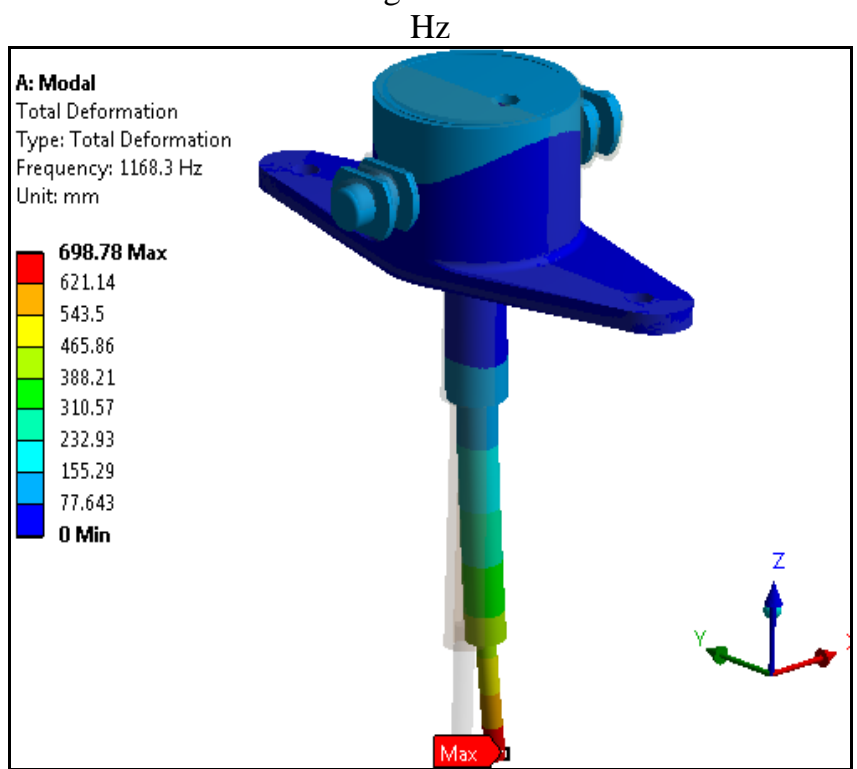

Fig 4 First Mode shape in T50 thermocouple

Mode-2: Element bending load in Y-direction at 1605.5 $\mathrm{Hz}$ 


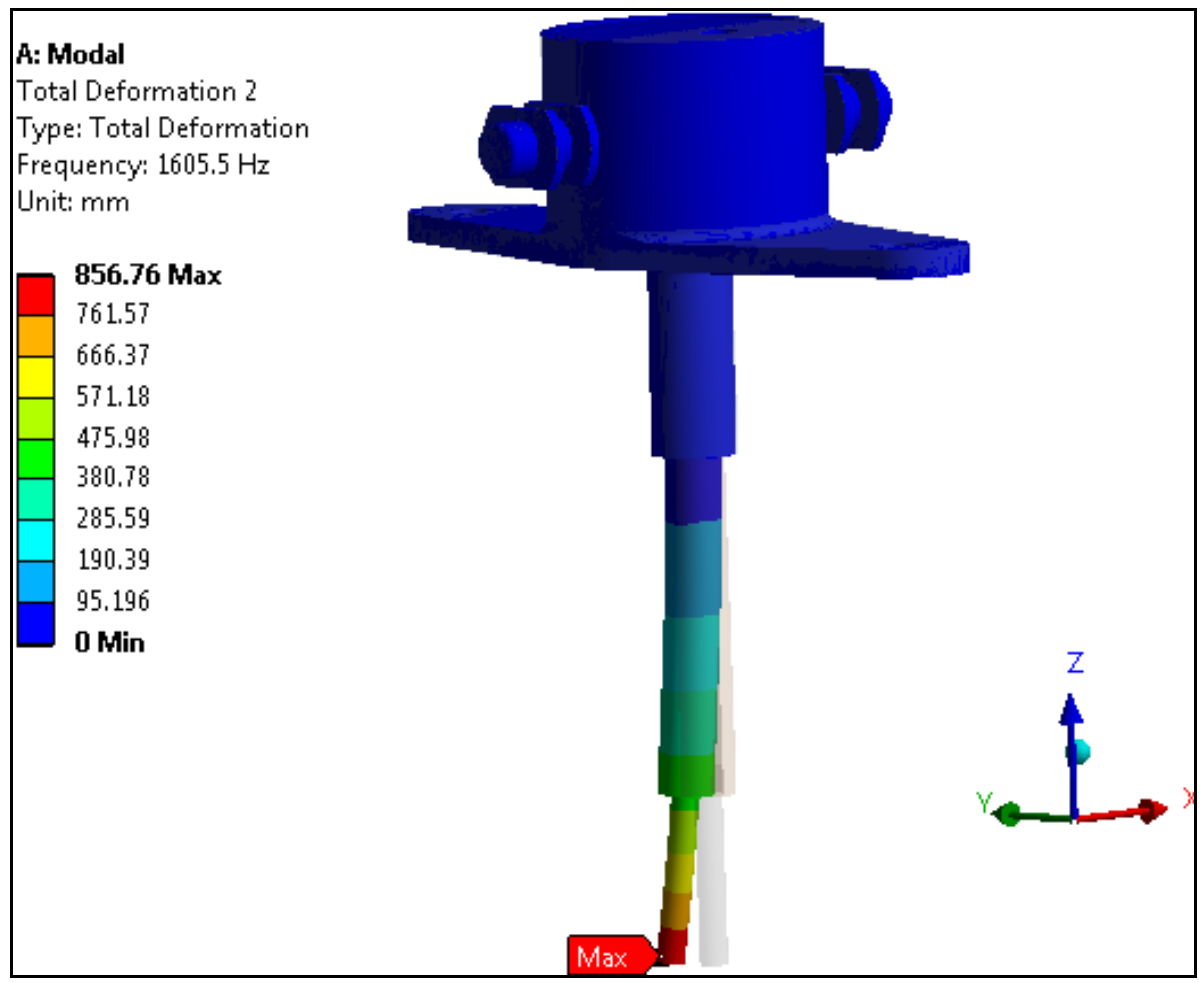

Fig 5 Second Mode shape in 50 thermocouple

\section{MASS PARTICIPATION FACTOR}

\section{X-Direction mass participattion details}

\begin{tabular}{|c|c|c|c|c|c|c|c|}
\hline \multirow[b]{3}{*}{ MoDe } & \multicolumn{5}{|c|}{ 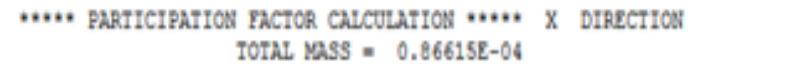 } & \multirow{3}{*}{$\begin{array}{l}\text { COMOLATTVE } \\
\text { Mass FRACTION }\end{array}$} & \multirow{3}{*}{$\begin{array}{l}\text { RATIO EFT.MASS } \\
\text { TO TOTAL MASS }\end{array}$} \\
\hline & & & & & & & \\
\hline & FREQUELACY & PERIOD & PARTIC. FACTCR & RATIO & EFTECTIV Mass & & \\
\hline 1 & 1168.26 & $0.85598 \mathrm{E}-03$ & $0.422018-03$ & 1.000000 & $0.178092 \mathrm{E}-06$ & 1.00000 & $0.205619 \mathrm{E}-02$ \\
\hline 2 & 1605.47 & $0.62287 \mathrm{E}-03$ & $0.15345 E-06$ & 0.000364 & $0.235467 \mathrm{E}-13$ & 1.00000 & $0.271855 \mathrm{E}-09$ \\
\hline gum & & & & & $0.178092 \mathrm{E}-06$ & & $0.205613 \mathrm{E}=02$ \\
\hline
\end{tabular}

\section{Y- Direction participation details}

\begin{tabular}{|c|c|c|c|c|c|c|c|}
\hline \multirow[b]{3}{*}{ MODE } & \multicolumn{7}{|c|}{ 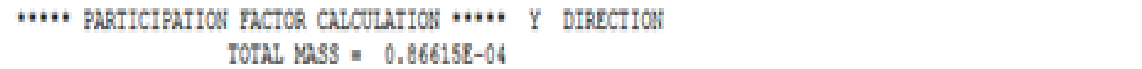 } \\
\hline & & & & & & CWNLATIV & RAITO EFF,MaSS \\
\hline & mEQOENCY & FERTOD & PARTIC. FACTOR & PATtO & EFFCTIVE Mass & vass muction & TO Totat yass \\
\hline 1 & 1169.26 & $0.85598 \mathrm{e}=03$ & $0.15520 \mathrm{E}-06$ & 0.000094 & $0.240874 E-13$ & $0.890696 \mathrm{t}-08$ & $0.2780978-09$ \\
\hline 2 & 1605.47 & $0.622878-03$ & $0.16443 E-02$ & 1.000000 & $0.2703722-05$ & 1.00000 & $0.312155 t-01$ \\
\hline 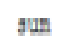 & & & & & $0.270372 \mathrm{E}=05$ & & $0.312155 \mathrm{E}=01$ \\
\hline
\end{tabular}

\section{Z- Direction participation details}

\begin{tabular}{|c|c|c|c|c|c|c|c|}
\hline \multirow[b]{3}{*}{ MODE } & \multicolumn{7}{|c|}{$\begin{array}{c}* * * * \text { PARTICIPATION FACTOR CALCULATION } * * * * 2 \text { DIRECTION } \\
\text { TOTAL MASS }=0.86615 \mathrm{E}-04\end{array}$} \\
\hline & & & & & & COMOLATIVE & RATIO EFF.MASS \\
\hline & FREQUENCY & PERIOD & PARTIC. FACTOR & RATIO & EFFECTIVE MASS & MASS FRACTION & TO TOTAL MASS \\
\hline 1 & 1168.26 & $0.85598 \mathrm{E}-03$ & $0.13342 \mathrm{E}-03$ & 1.000000 & $0.178020 \mathrm{E}-07$ & 0.999989 & $0.205530 \mathrm{E}-03$ \\
\hline 2 & 1605.47 & $0.62287 \mathrm{z}-03$ & $0.44914 \mathrm{E}-06$ & 0.003366 & $0.201725 \mathrm{E}-12$ & 1.00000 & $0.232899 \mathrm{E}-08$ \\
\hline sum & & & & & $0.178022 E-07$ & & $0.205532 \mathrm{E}-03$ \\
\hline
\end{tabular}


Takeaway: by observing mass participation factor and effective mass contribution, we can concluded that $\mathrm{Y}$ direction is having a dominant mass participation and hence Y-direction is selected for further vibration study.

\section{B. Harmonic Response:}

Harmonic analysis was carryout for the frequency range of $0-2000 \mathrm{~Hz}$ with damping ratio of $2 \%$ and in the harmonic analysis an acceleration load of $9814.56 \mathrm{~mm} / \mathrm{s}^{2}$ is applied in Y-direction.

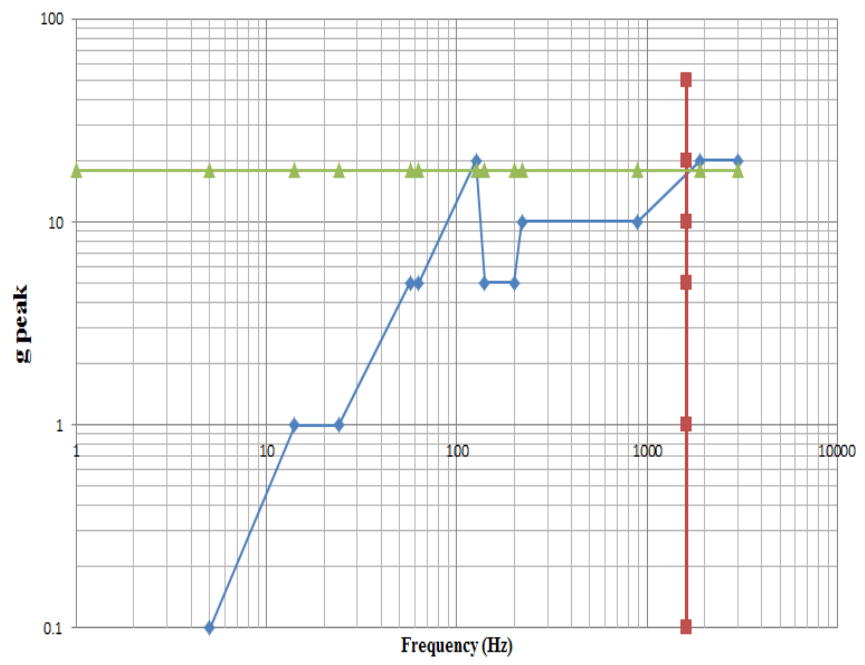

Graph 1. Response curves for scaling factor

From the above graph it is clear that, actual $\mathrm{G}$ at $1605.5 \mathrm{~Hz}$ is $18 \mathrm{G}$. So the scaling factor of 18 is used to get the actual response and stress results.

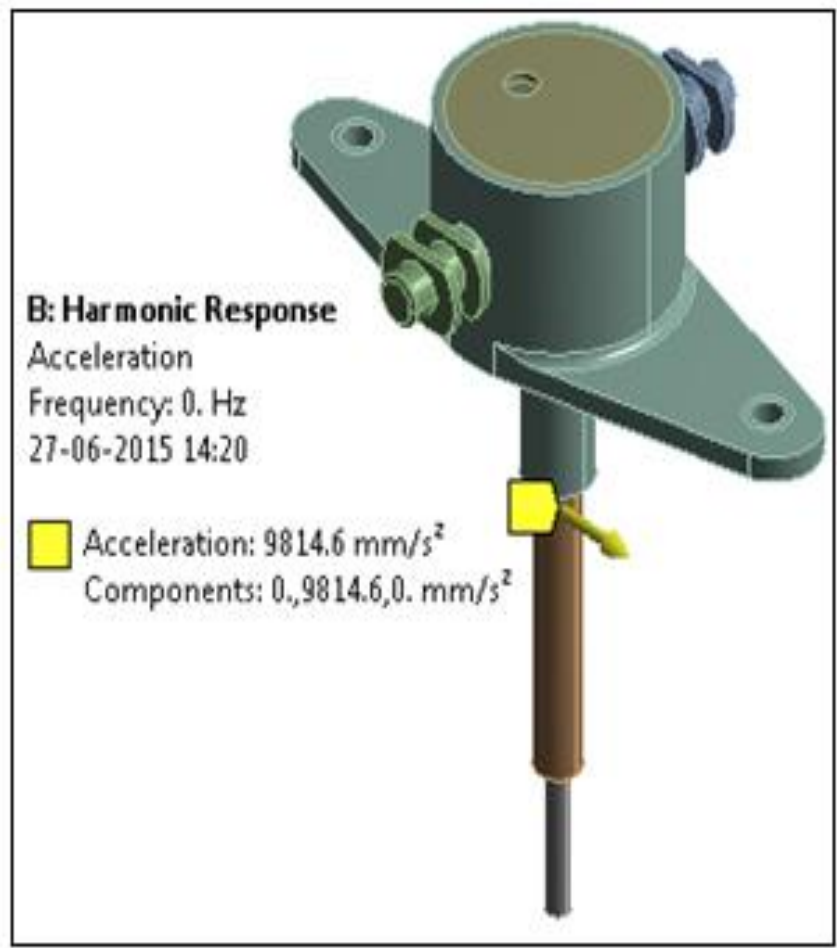

Fig 6 Acceleration load is applied to T50 thermocouple in Y-direction

\section{RESULTS AND DISCUSSION - HARMONIC}

ANALYSIS

Frequency Response

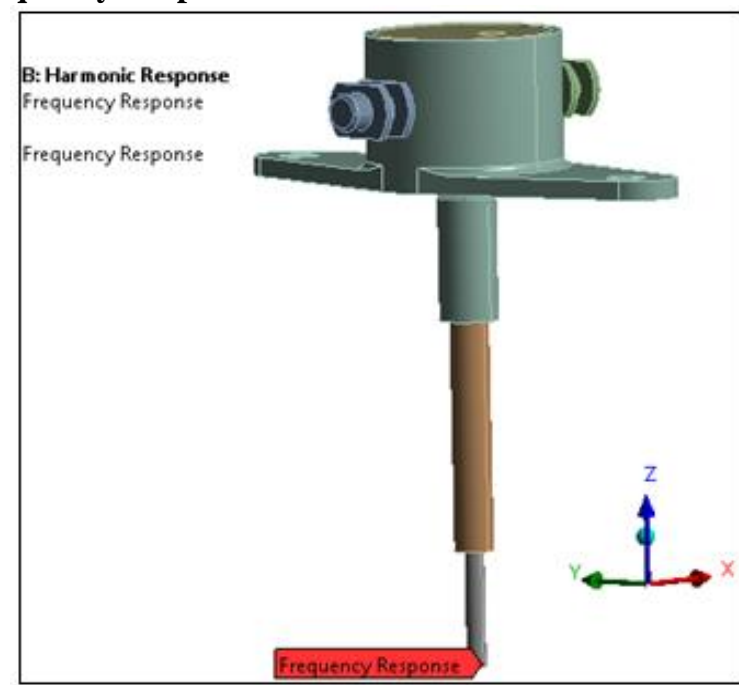

Fig 7 Acceleration response locations- Element

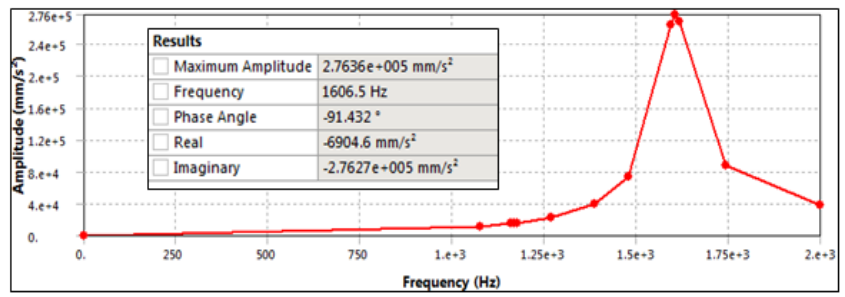

Graph 2 Acceleration response plot

\begin{tabular}{|l|l|}
\hline & Acceleration $\left(\mathrm{mm} / \mathrm{s}^{2}\right)$ \\
\hline Output Response for 1G & $2.76 \mathrm{E}+05$ \\
\hline Output Response for 18G & $4.97 \mathrm{E}+06$ \\
\hline $\begin{array}{l}\text { Amplification Factor } \\
\text { (Output/Input) }\end{array}$ & $\frac{27 \mathrm{EI}}{7 \mathrm{E} 1 \mathrm{E}}=\mathbf{2 8 . 1 5}$ \\
\hline
\end{tabular}

Total Deformation

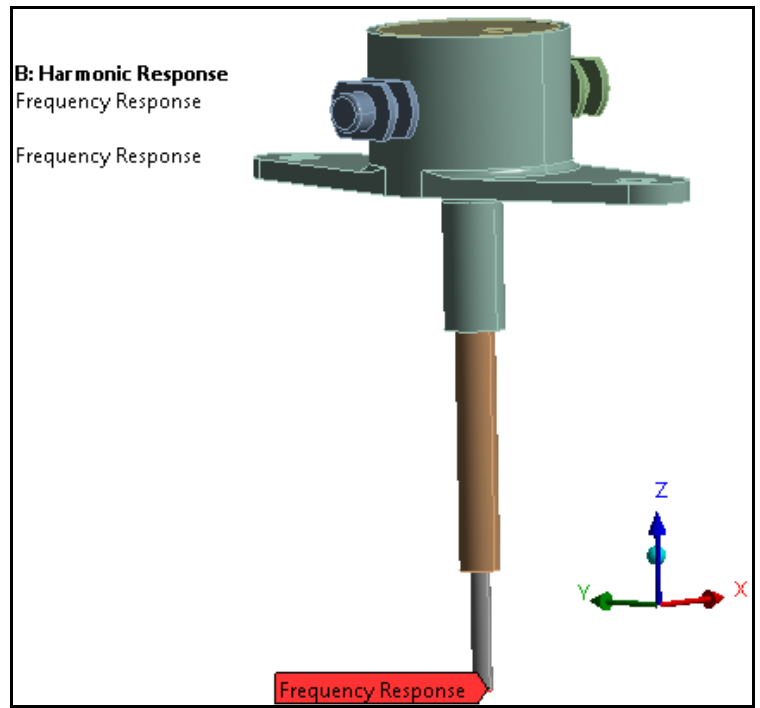

Fig 8 Deformation response locations- Element 


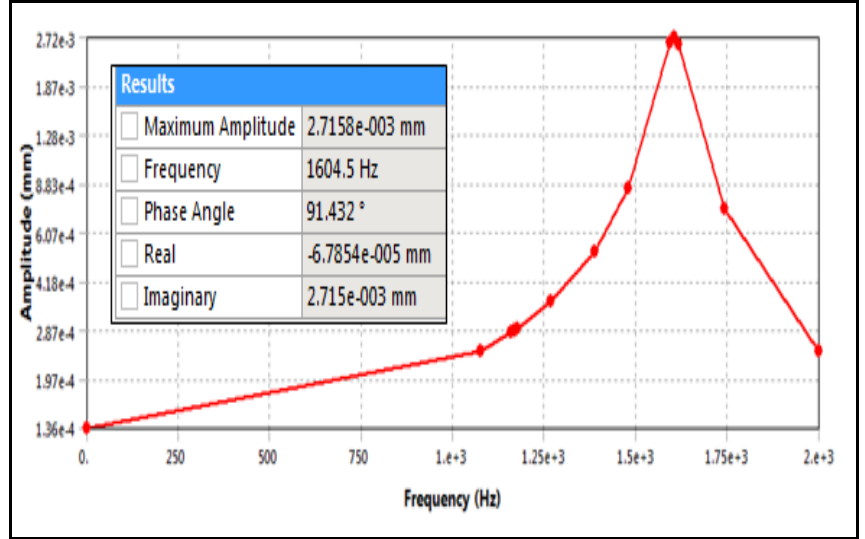

Graph 3 Deformation Response Plot

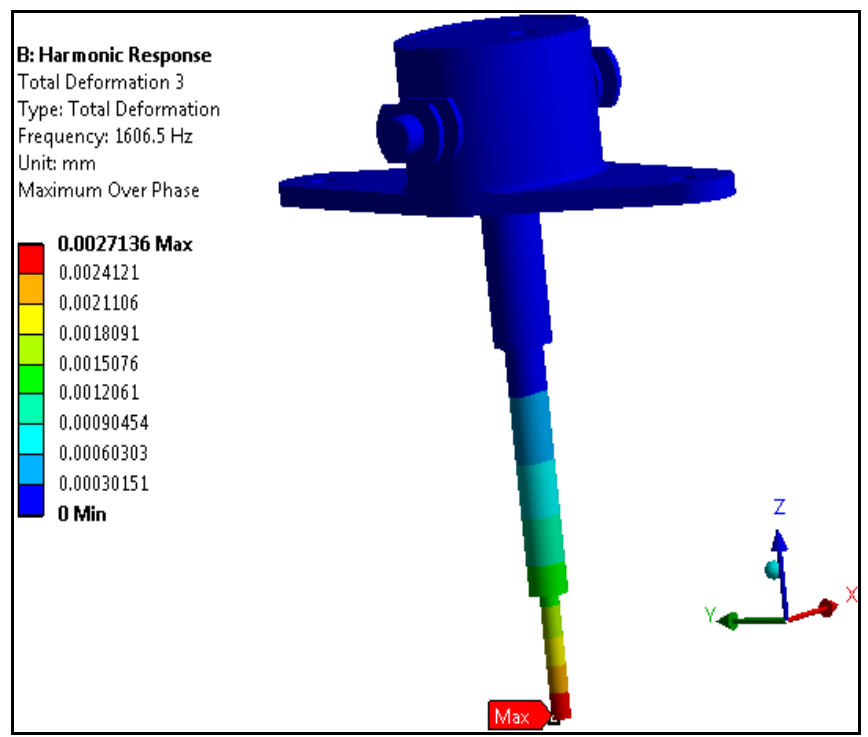

Fig 9 Deformation plot at $1605.5 \mathrm{~Hz}$

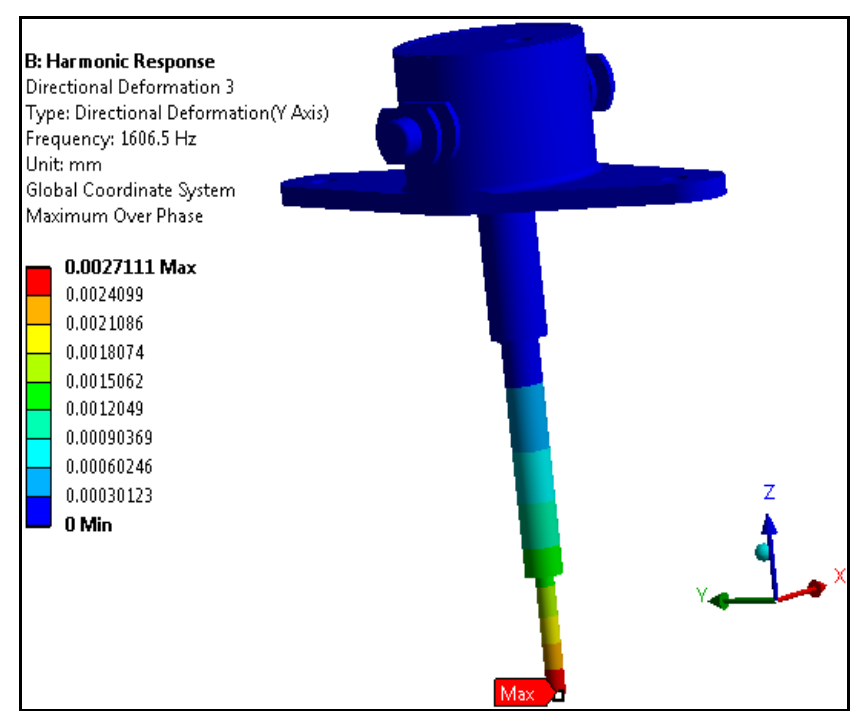

Fig 10 Directional deformation (Y-Axis) plots at $1605.5 \mathrm{~Hz}$

\begin{tabular}{|l|l|}
\hline & Deformation $(\mathrm{mm})$ \\
\hline Output Response for 1G & $2.72 \mathrm{E}-03$ \\
\hline Output Response for 18G & $4.90 \mathrm{E}-02$ \\
\hline
\end{tabular}

\section{Max Stress Plot - Element:}

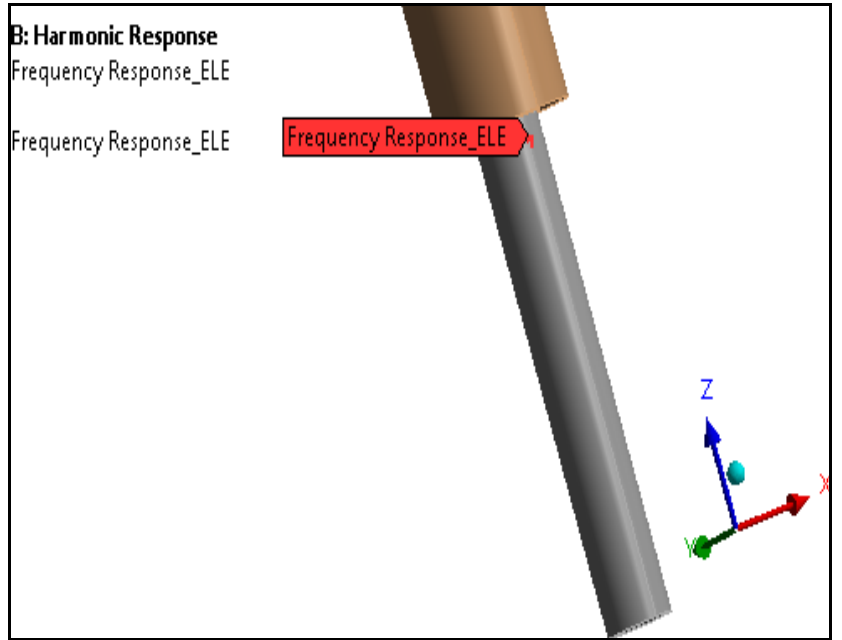

Fig 11 Frequency response locations- Element

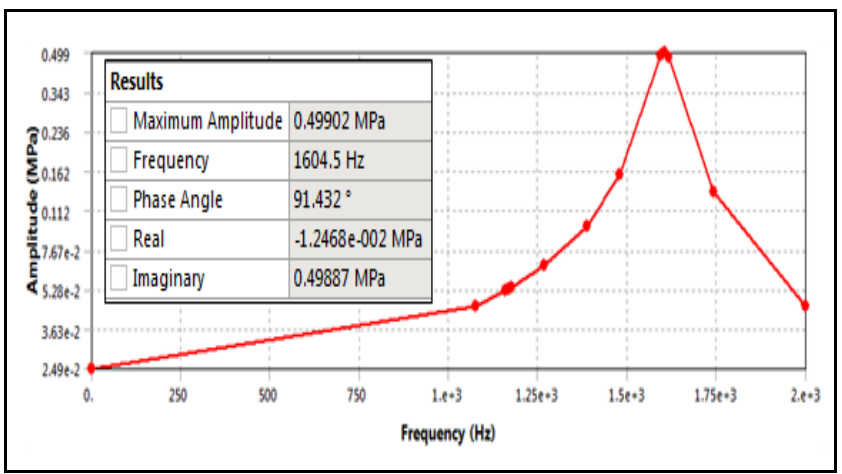

Graph 4 Frequency response plot-Elements

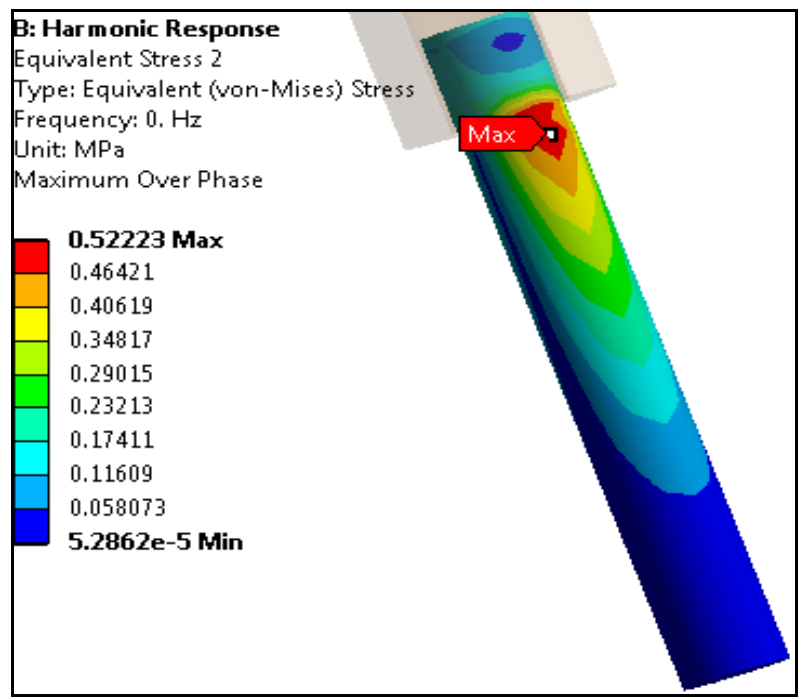

Fig 12 Equivalent (Von-Mises) Stress- Element

\begin{tabular}{|l|l|}
\hline & $\begin{array}{l}\text { Element } \\
(\mathrm{MPa})\end{array}$ \\
\hline Output Response for 1G & $\mathbf{0 . 5 2}$ \\
\hline Output Response for 18G & $\mathbf{9 . 3 6}$ \\
\hline
\end{tabular}




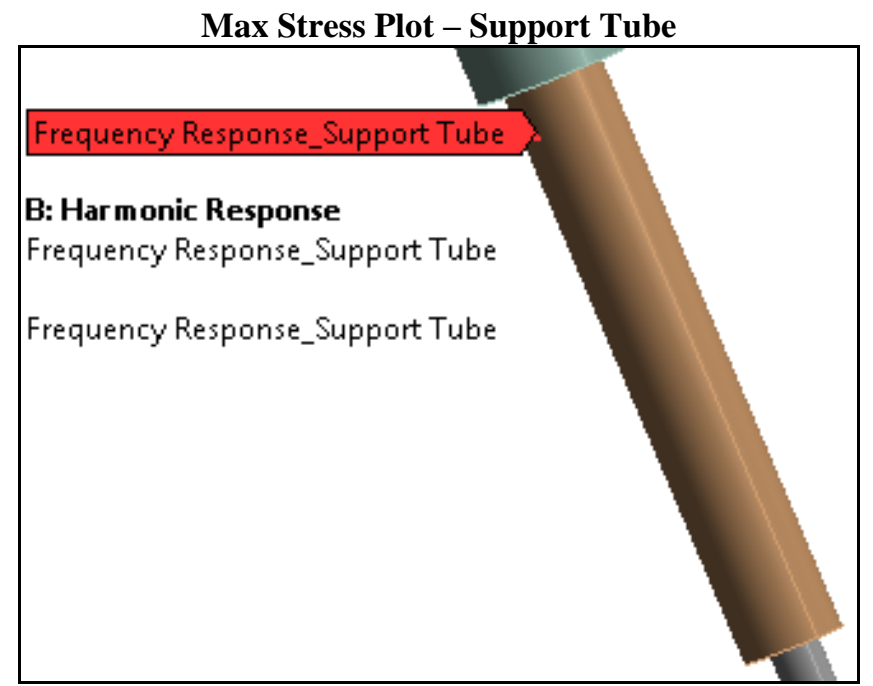

Fig 13 Frequency response locations- Support Tube

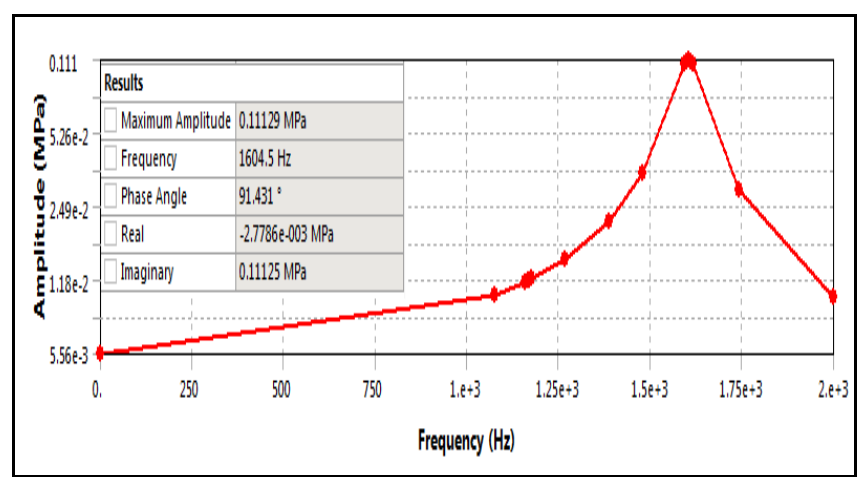

Graph 5 Frequency response plot-Supports Tube

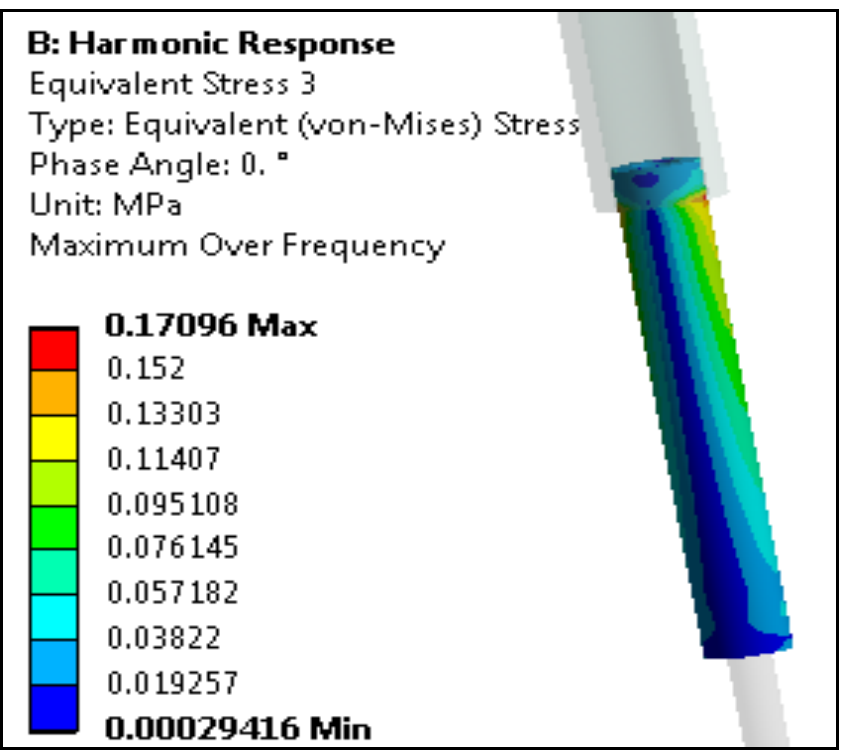

Fig 14 Equivalent (Von-Mises) Stress- Support Tube

\begin{tabular}{|l|l|}
\hline & $\begin{array}{l}\text { Support tube Stress } \\
\text { (MPa) }\end{array}$ \\
\hline Output Response for 1G & 0.17 \\
\hline Output Response for 18G & 3.06 \\
\hline
\end{tabular}

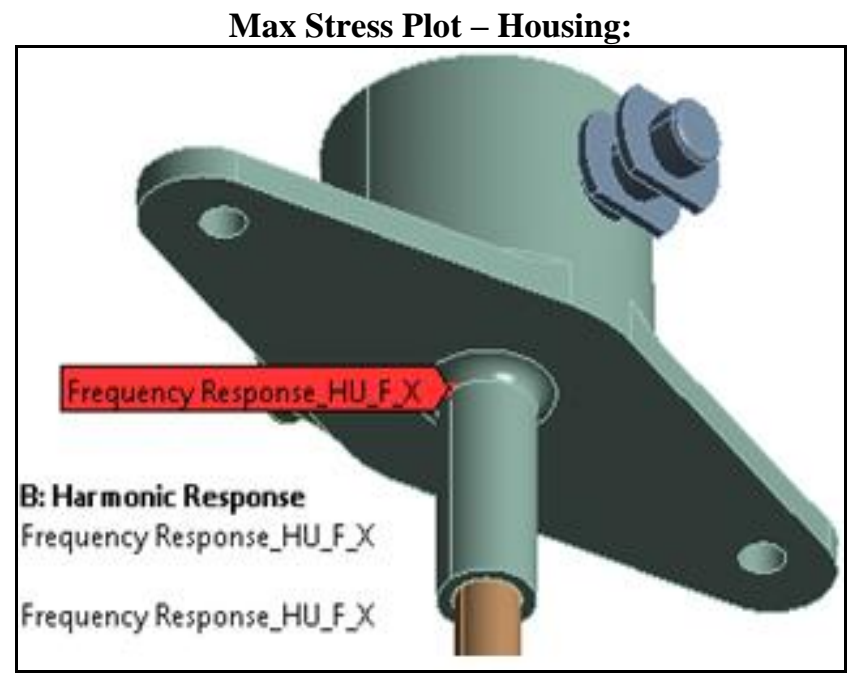

Fig 15 Frequency response locations- Housing

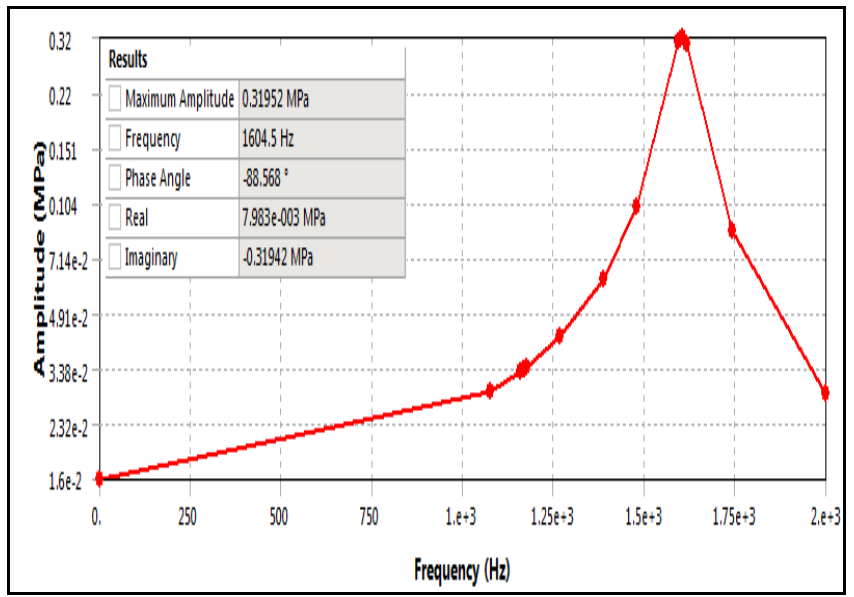

Graph 6 Frequency response plot-Housing

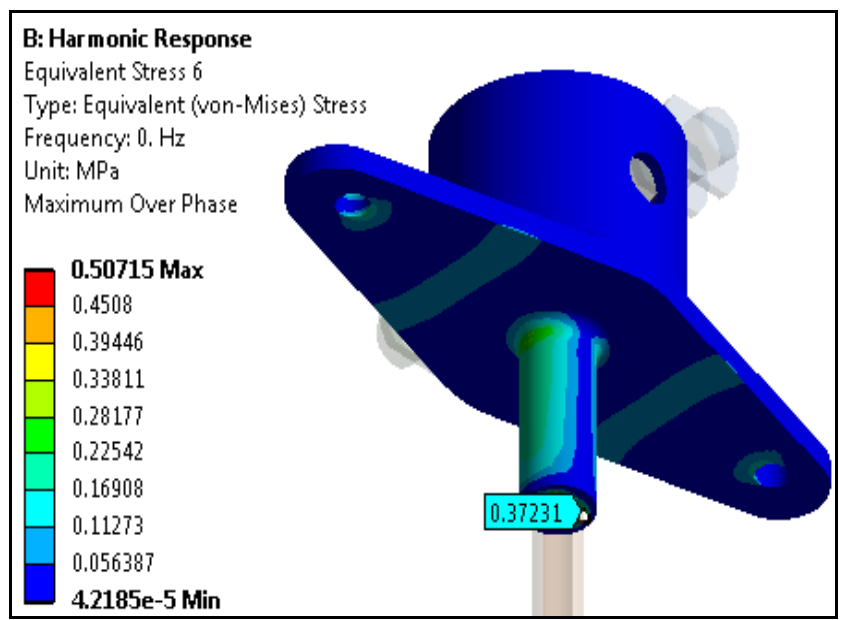

Fig 16 Equivalent (Von-Mises) Stress- Housing

\begin{tabular}{|l|l|}
\hline & $\begin{array}{l}\text { Housing Stress } \\
(\mathrm{MPa})\end{array}$ \\
\hline Output Response for 1G & 0.5 \\
\hline Output Response for 18G & 9.0 \\
\hline
\end{tabular}




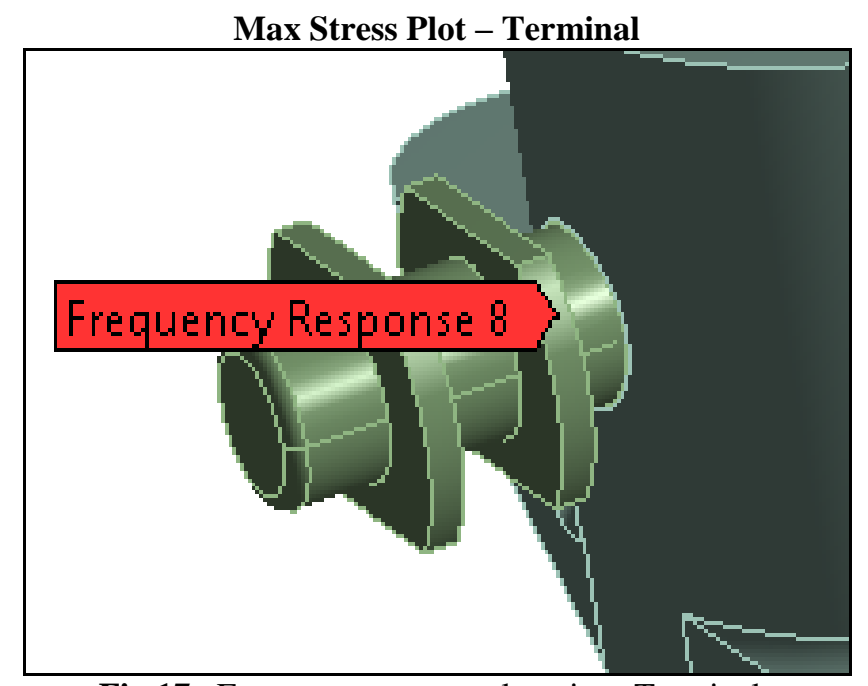

Fig 17 Frequency response location- Terminals

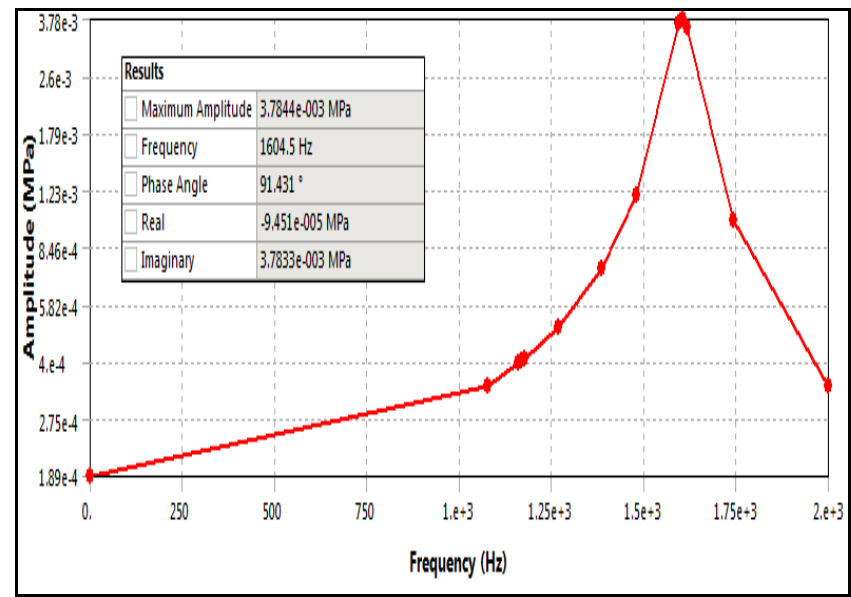

Graph 7 Frequency response plot-Terminals

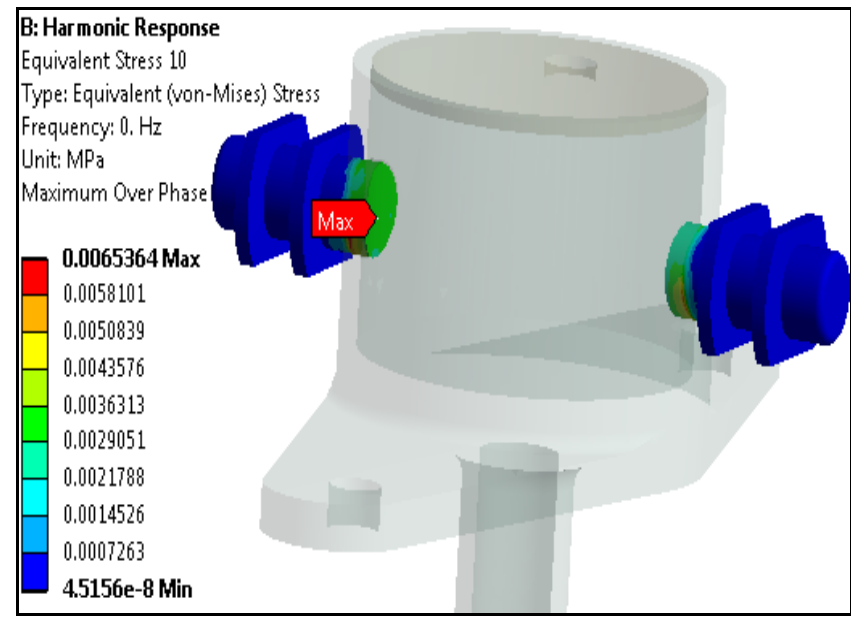

Fig 18 Equivalent (Von-Mises) Stress- Terminal

\begin{tabular}{|l|l|}
\hline & $\begin{array}{l}\text { Terminal Stress } \\
(\mathrm{MPa})\end{array}$ \\
\hline Output Response for 1G & $\mathbf{0 . 0 0 6 5}$ \\
\hline Output Response for 18G & 1.17 \\
\hline
\end{tabular}

\section{CONCLUSION:}

$>\quad$ Vibrational characteristics like natural frequency and mode shapes are obtained using modal analysis by this predict of resonance is possible.

$>$ Mode-2 with natural frequency of $1605.5 \mathrm{~Hz}$ is considered as critical mode as it is having high effective mass in $\mathrm{Y}$ direction compared to $\mathrm{X} \& \mathrm{Z}$ direction and mass participation Ratio 1.

$>$ Steady- state response of a T50 thermocouple is obtained using Harmonic response analysis.

$>$ It is analysed for the critical frequency (mode-2) in $\mathrm{Y}$ direction.

$>$ Graph of displacement and stress is plotted against the frequency; by this peak stress is found. The obtained results are satisfactory and fall below the limit

\section{SCOPE FOR FUTURE WORK}

$>$ Exploring other cost effective materials with minimum weight.

$>$ Exploring other alternative manufacturing processes like additive manufacturing.

\section{REFERENCE}

[1]. J.V.Pearce, G.Machin, T.Ford, S.Wardle "Optimizing Heat Treatment of Gas Turbine Blades with a $\mathrm{Co}-\mathrm{C}$ Fixed Point for Improved In-service Thermocouples", 2008.

[2]. Mike Beckman and Luis Chioye, "Precision Thermocouple Measurement with the ADS1118", 2011.

[3]. Ian M. Tougas, Matin Amani and Otto J. Gregory, "Metallic and Ceramic Thin Film Thermocouples for Gas Turbine Engines”, 2013

[4]. Soumen De, Ravi Yoganatha Babu, Viany Bhaskar, Achalesh Kumar Pandey, Richard John Rucigay, "System and Method for Prediction of Gas Turbine Trips Due To Thermocouple Failures" ,2010.

[5]. Anafld A Kulkarnl, Davld J- Mltchell, Edward R. Roesch, "Thermocouple for Gas Turbine Environments", 2011.

[6]. J. H. Visser, and R. E. Soltis "Automotive Exhaust Gas Sensing Systems", 2001.

[7]. R.E Young "Exhaust Gas Temperature Analyzing System and Method", 1970.

[8]. William J. Podl, Hanover Park, "Diesel Engine Exhaust Temperature Monitor", 1978.

[9]. "RTCA DO-160 Data Hand book"

[10]. "Military Data Hand Book"

[11]. "Practical Finite Element method" by Nithin S Gokule and Sanjay S Deshapande. 